\title{
Energy performance and summer thermal comfort of traditional courtyard buildings in a desert climate
}

\author{
Zahra Zamani ${ }^{1}$, Shahin Heidari ${ }^{1}$, Maryam Azmoodeh ${ }^{2}$, Mohammad Taleghani ${ }^{3 \text { * }}$ \\ 1 University of Tehran, Tehran, Iran \\ 2 Imam Khomeini International University, Qazvin, Iran \\ ${ }^{3}$ University of Salford, Manchester, UK
}

\begin{abstract}
Courtyards have been traditionally used as a passive design strategy in desert climates. However, few studies have quantified the thermal performance of this building archetype. This paper explored the indoor and outdoor thermal conditions of a typical courtyard house in Iran. The study was performed in two phases. The first phase showed the effect of the position of the zones located in four sides of the courtyard on their indoor energy use and indoor thermal comfort. The results showed that the east and west sides of the courtyard require the highest cooling demand due to the solar radiation in summer time. Furthermore, maximum discomfort hours occurred in the east zone. In the second phase, hourly air temperature inside and outside of the courtyard were compared during the longest day of the year ( $21^{\text {st }}$ of June). The results showed that inside of the courtyard was $1.2^{\circ} \mathrm{C}$ cooler than the outside on average. Moreover, it was observed that the temperature fluctuations outside of the courtyard were higher than the inside. To sum up, the results showed that courtyards can provide a cooler microclimate in summer time.
\end{abstract}

\section{Keywords}

Courtyard housing; microclimate; thermal comfort; energy demand

\footnotetext{
*Corresponding author: Mohammad Taleghani m.taleghani@salford.ac.uk
} 


\section{Introduction}

Dwelling on courtyards dates back to thousands of years ago in hot and arid climates like Iran [1]. This building archetype was developed to protect the dwellers from the harsh outdoor climate. Different types of courtyards appeared in China, Middle East, North Africa, and South Europe [2]. Yet, all have the same principal in common; customising the microclimate of the courtyard for the thermal preference of the dwellers. In arid climates, water ponds and vegetation are added to the courtyard to increase the humidity level [3-5]. In humid climates, courtyards have porous facades to boost the ventilation rate $[6,7]$. In recent decades, covering the roof of courtyard with glazing (atrium) gave more opportunities to the dwellers to control their microclimate [8-12].

Some studies have quantified the influence of local climate on the thermal performance of courtyards. Muhaisen et al., [13] studied the optimum orientation of courtyards. They showed that for the hot-humid climate of Kuala Lumpur, northeast-southwest orientation for the long axis of the courtyard provides maximum hours of thermal comfort. Regarding the geometry of courtyards, Yaşa and OK [14] studied seven courtyard buildings in Diyarbakir, Turkey. They showed that the optimum dimensions are the ones that protect the courtyard in summer, and increase the solar gains in winter. Yang et al., [15] looked at other parameters in courtyards like the heat capacity, albedo and conductivity of courtyard walls in Beijing, China. They showed that the height and thermal mass of the facades are the most important factors influencing the microclimate of the courtyards. They found out that by increasing the thermal mass of the facades, peak temperature during summer time could be reduced for the dwellers.

Reduction of heat during the peak time can save energy demand from power stations in critical periods $[16,17]$. The source of the heating and cooling energy is still fossil fuels in most of the developing countries. Courtyards can play a significant role in reducing cooling energy demand. Therefore, this study will quantify the impact of courtyard buildings on energy use and thermal comfort in the hot and arid climate of Isfahan, Iran. A typical courtyard house will be investigated as a case study. For the first time, this research will explore the thermal performance of different zones within a courtyard. This can help designers understand what type of activity/use should be allocated to different zones. Apart the indoor environment, the outdoor temperature within the semi-open space of the courtyard is compared with the air temperature outside of the courtyard building. To perform these experiments, computer simulations for indoor environment, along with micrometeorological simulations for outdoor thermal conditions of the courtyard will be performed. Regarding the innovation of this paper, it should be noted that most of the studies on courtyard buildings and passive design strategies are focused on either indoor or outdoor environments, solely [18]. In this paper, both scales are studied. First, different thermal zones inside the courtyard house were investigated; and then the outdoor open spaces of the courtyard were studied. It is shown how the air temperature is different inside and outside of the courtyard. Furthermore, currently published studies refer to the indoor environment of the courtyard buildings as one single zone. In this paper, the indoor environment of the courtyard house is divided into four separate zones. Solar gains, operative temperature, daylight factor, heating and cooling energy use, and thermal comfort in these zones are compared. This gives a better definition of indoor thermal zones to indoor designers. Results of this study are useful for architects, landscape designers and planners who aim to incorporate courtyard buildings in their design projects. 


\section{Methodology}

This paper studies the indoor and outdoor environments of a courtyard house. The building (our case study) was built in 1750 by bricks. Its spaces are laid out along the four sides of a rectangular courtyard (Figure 1). Four banquet halls are set in the centre of the courtyard sides. It is a two-story building with basement. The dimensions of the building are $20.5 \mathrm{~m}$ wide in east-west direction, and $29 \mathrm{~m}$ long. It has an open space courtyard, $11 \times 15.4 \mathrm{~m}^{2}$. The building was designed as a residential unit.
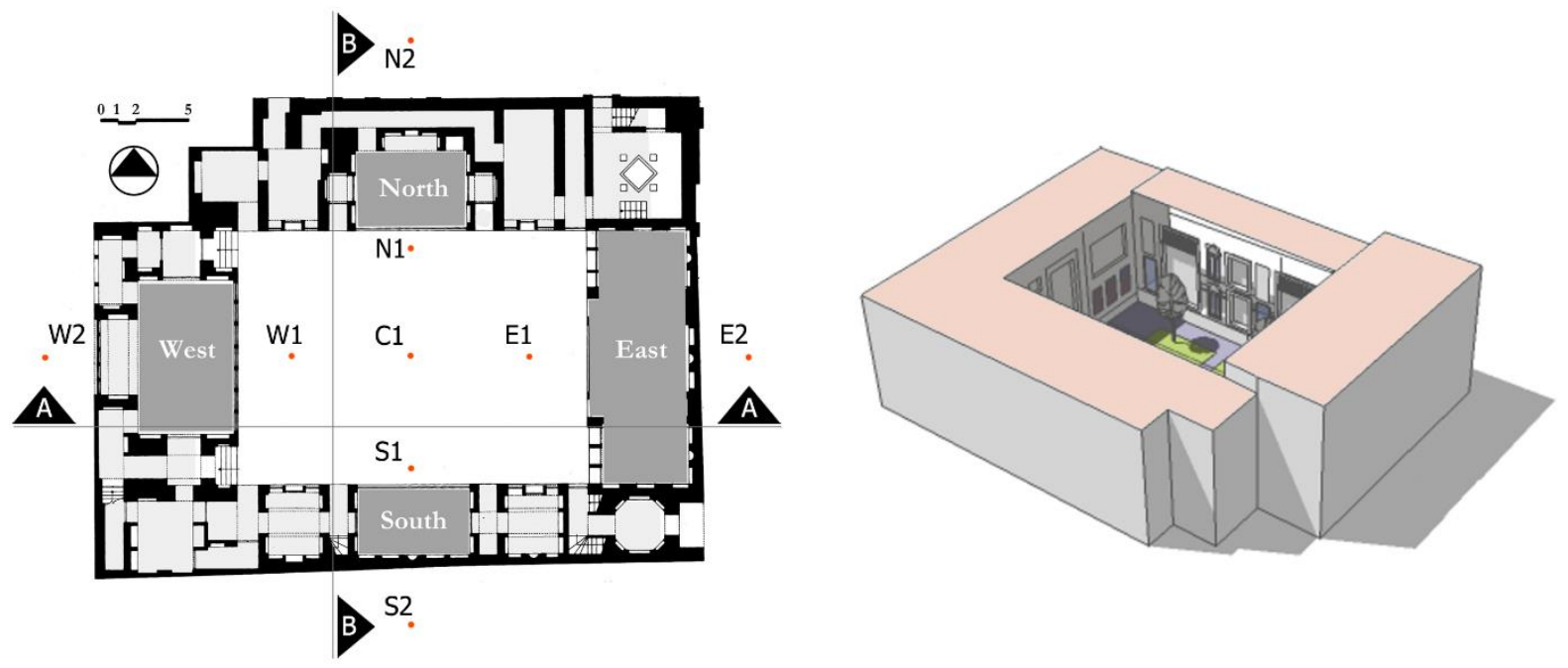

Figure 1: The plan of the residential courtyard house, image after [19] (left); and the corresponding 3D model of the house visualised by Sketchup (right).

\subsection{Phase 1: Indoor thermal conditions}

In Phase 1, building energy simulation was performed for the indoor environment of the house. The aim was to investigate the indoor thermal performance of different thermal zones. The zones are located in north, south, east and west sides of the courtyard. To compare the thermal performance of the zones, these parameters were considered: a) solar gain, b) operative temperature, c) daylight factor, d) heating and cooling energy demands, and e) indoor thermal comfort. To perform the simulations, DesignBuilder [20] was employed. This software uses Energy Plus developed by the US Department of Energy [21]. To perform the simulations, weather data of Isfahan was retrieved from [22]. The simulation of the courtyard house with its different zones was done for a full year. DesignBuilder is used in plenty of research projects related to the impact of building geometries on indoor environment [23-25].

\subsection{Phase 2: Outdoor thermal conditions}

In Phase 2, the microclimate of the open space of the courtyard house was studied. This phase of the study compared the microclimatic differences inside and outside of the courtyard house. 
Outdoor thermal conditions were simulated with ENVI-met v.4 [26]. This software is a high resolution computational fluid dynamic model, which solves Reynold averaged nonhydrostatic Navier Stockes equations [27]. Air temperature, wind speed and mean radiant temperature are among the main outputs of the software. These make ENVI-met suitable for the evaluation of outdoor thermal conditions in a neighbourhood scale. Several studies have used such micro-meteorological outputs of ENVI-met to calculate outdoor thermal comfort [28, 29]. ENVI-met has been validated by various field measurement campaigns. In most of these studies, simulated and measured sets of air temperature are compared. For instance, these two studies validated their ENVI-met results within courtyard buildings:

- Kleerekoper et al., [30] measured air temperature within a courtyard in Delft (The Netherlands), and modelled the same building in ENVI-met for two days. Calculation of root mean square deviation showed that the average difference between the simulated and measured air temperatures were $0.7^{\circ} \mathrm{C}$ and $1.3^{\circ} \mathrm{C}$ in those two days.

- Forouzandeh [31] compared the measured and simulated air temperature, relative humidity, wind speed and mean radiant temperature in a courtyard in Hannover, Germany. The study showed that the root mean square deviation (RMSD) for the above mentioned factors were $0.73{ }^{\circ} \mathrm{C}, 3.34 \%, 0.01 \mathrm{~m} / \mathrm{s}$, and $8.44{ }^{\circ} \mathrm{C}$, respectively.

For this research, the courtyard house and its surrounding environments were simulated for the longest day of the year, $21^{\text {st }}$ of June (Table 1). To compare the indoor and outdoor microclimates of the courtyard house, five receptors were put in the simulation domain (see the red dots in Figure 1 left). Four of them are located in north, south, east and west sides of the courtyard and one of them is in the centre of the courtyard. In addition, four other receptors are located outside of the courtyard.

Table 1. Conditions used for simulating the house with ENVI-met.

\begin{tabular}{|l|l|}
\hline Location & Isfahan, Iran $\left(32.6^{\circ} \mathrm{N} ; 51.6^{\circ} \mathrm{E}\right)$ \\
\hline Simulation day & 21.06 .2016 \\
\hline Simulation start time & $01: 00 \mathrm{am}$ \\
\hline Simulation period & $30 \mathrm{~h}$ \\
\hline Grid size $(\mathrm{x} \times \mathrm{y} \times \mathrm{z})$ & $1 \times 1 \times 1 \mathrm{~m}^{3}$ \\
\hline Initial air temperature & $27.5^{\circ} \mathrm{C}$ \\
\hline Wind speed & $2 \mathrm{~m} / \mathrm{s}$ \\
\hline Wind direction & $245^{\circ}$ \\
\hline Relative humidity & $17.8 \%$ \\
\hline Building indoor temperature & $20.0^{\circ} \mathrm{C}$ \\
\hline
\end{tabular}

\subsection{Current and future climate of Isfahan}

Isfahan is the third largest city of Iran. This city is under the influence of the desert from the north and east. In the summer, the temperature reaches $36^{\circ} \mathrm{C}$. Nevertheless, due to the lower temperature during the night, it gets pleasant and comfortable. In winter however, the day temperature is moderate but extreme coldness happens during the night. According to several climatic classifications [32-34], Isfahan is in the hot arid zone of Iran. 
Figure 2 shows the current climate of Isfahan versus 2050 climate scenario. This figure shows monthly air temperature sets. The maximum air temperature in these two climate conditions (current and 2050) will be in July. An increase of $3.2^{\circ} \mathrm{C}$ is expected in the average temperature of Isfahan by 2050 . On average, the air temperature will be $2.6{ }^{\circ} \mathrm{C}$ hotter in 2050. This increase of temperature can significantly affect cooling energy demand and human thermal comfort.

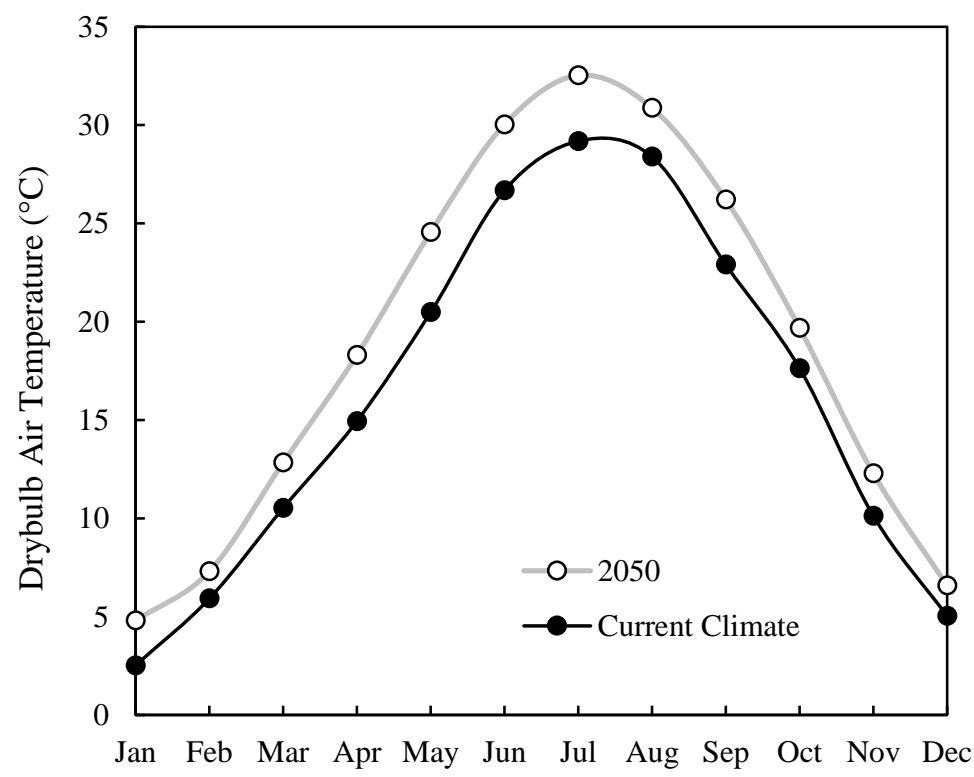

Figure 2: Monthly dry-bulb outdoor air temperature of Isfahan in current climate and 2050.

\section{Results}

\subsection{Indoor thermal conditions}

\subsubsection{Solar gains in different zones}

Regarding the solar gains, orientation can substantially change the results. To understand how the four zones are affected by the sun, Figure 3 illustrates the sun path diagram of the city in the longest and shortest days of the year $\left(21^{\text {st }}\right.$ of June and $21^{\text {st }}$ of December, respectively). The zones have openings to the centre of the courtyard, so the north zone receives solar radiation only from the south openings, and the east zone receives sun only from the west, and so on. 


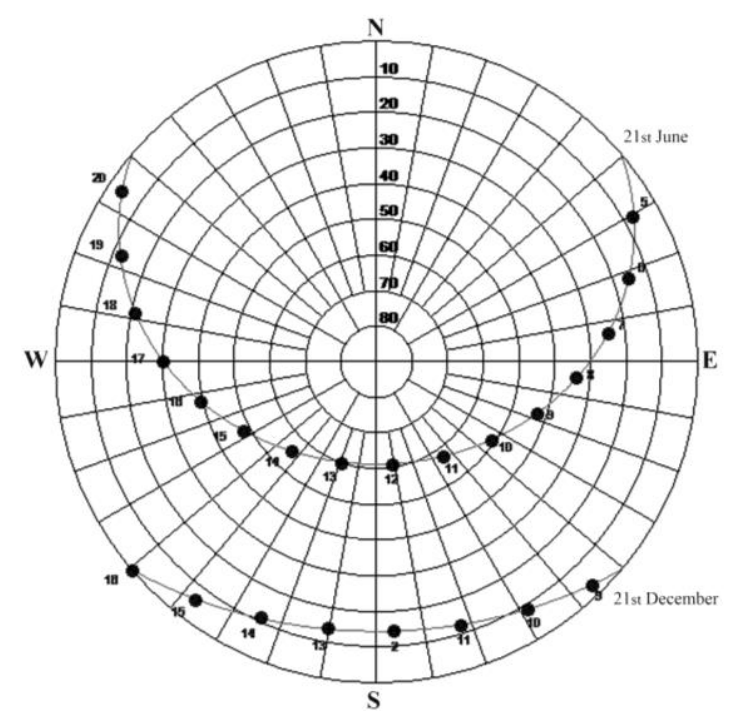

Figure 3: The Sun path diagram for the longest ( $21^{\text {st }}$ of June) and shortest (21 $1^{\text {st }}$ of December) day of Isfahan.

In winter, the altitude of the sun is low, and it rises from south east and sets to south west. This allows the north zone to receive sun from the southern openings. The other zones receive limited solar radiation in winter time. As figure 4 shows, there is an obvious difference between the north zone and the other zones (around $6 \mathrm{kWh} / \mathrm{m}^{2}$ ).

In summer, the altitude of the sun is in the highest. At this moment, all zones receive direct and diffused solar radiation. Despite this fact, the north zone receives more solar radiation compared to the south zone (which receives sun from the north openings). In this regard, the northern zone receives the highest solar radiation throughout the year $\left(71.3 \mathrm{kWh} / \mathrm{m}^{2}\right)$. This amount is the lowest for the south zone $\left(27.8 \mathrm{kWh} / \mathrm{m}^{2}\right)$, and the east and west zones receive similar radiation because of the symmetry in the sun path $(42.1$ and $37.8 \mathrm{kWh} / \mathrm{m}^{2}$, respectively).

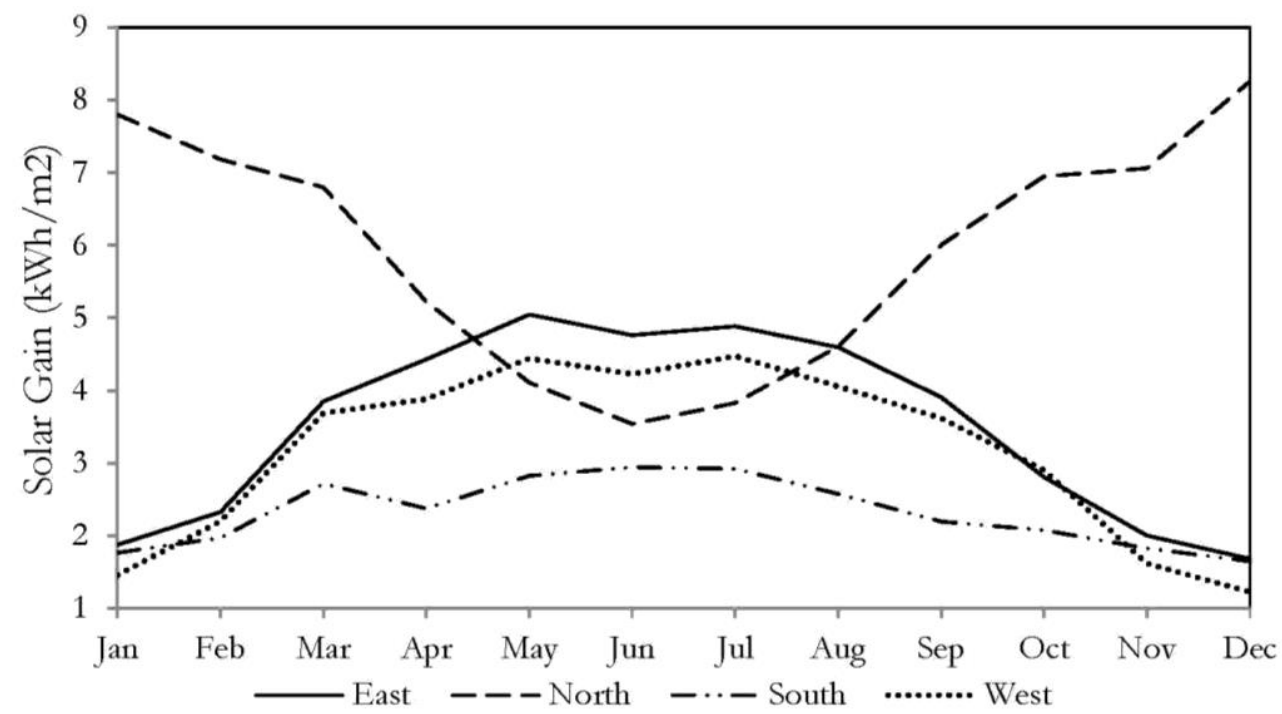

Figure 4: Monthly solar gains of different zones. 
The indoor environment of a thermal zone is directly dependant on its heat exchange with outdoor environment. Operative temperature is derived from air temperature and mean radiant temperature. Considering the different amounts of solar radiation gained by the different zones, monthly averages of operative temperature are illustrated in Figure 5. These temperature ranges can indicate the cooling energy demands for each thermal zone.

Based on the solar gain diagram (Figure 4), the north zone of the house has the highest solar radiation received during the winter time. This increases the indoor operative temperature in the north zone. While received solar radiation declines in summer in the north zone, the operative temperature becomes lower than east and west zones (because of the angle of sun). During summer, east and west zones have the highest received solar radiation with the highest operative temperatures. The south zone has the least gains during the year, and consequently, lowest temperature among the zones.

Temperature differences between the zones bring the opportunities and attentions to the zones regarding the overheating risk and thermal discomfort (especially during the free running time). From June to August, the east zone is the hottest zone (Figure 5). This can affect a designer's decision regarding the arrangement of the indoor activities. Moreover, the schedule of activities during a day might be affected by the thermal performance of zones.

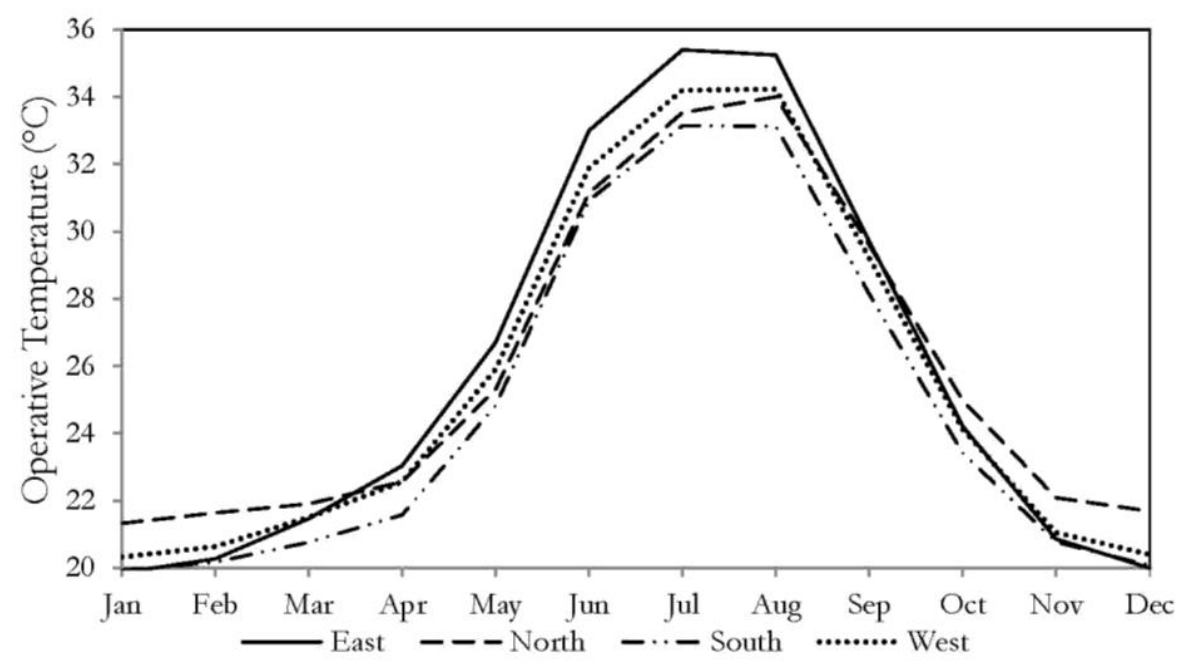

Figure 5: Monthly averages of indoor operative temperatures in different zones.

\subsubsection{Daylight factor}

Regarding the natural daylight captured by the different zones of the house, Figure 6 shows the map of daylight factor. Daylight factor in the east, north, west and south zones are $0.813,0.848,1.368$ and 1.289 , respectively. This shows that the east zone receives the least sun (during the evening), and the north zone the most (the whole day). This is correlated to the solar gain by the sun. 


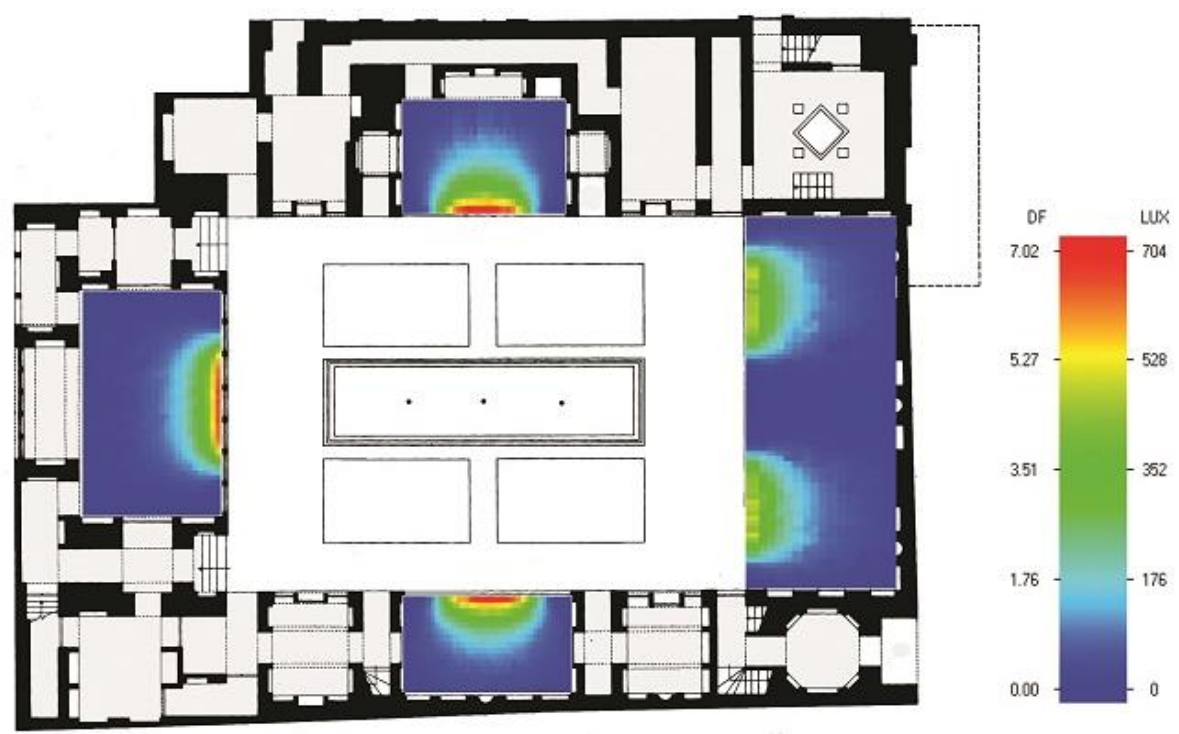

Figure 6: Daylight factor in different zones of the house.

\subsubsection{Energy use}

Investigating the thermal behaviour of the four zones allows interpreting the actual effect of these zones on their energy performances in a year. In Figure 7, monthly heating and cooling energy demands of the zones are separately illustrated.

Regarding the heating demands, from May till October, there is no need for heating because of the received solar radiation. For the rest of the year, the south and east zones need higher energy demand for heating. These zones need 13 and $14 \mathrm{kWh} / \mathrm{m}^{2}$ in a year for heating, respectively. Moreover, the north zone which has the highest amount of solar radiation during the winter needs $5 \mathrm{kWh} / \mathrm{m}^{2}$ per year. These results show that the east and south zones have the most heating energy demands.

Concerning the cooling demands of the zones, east zone has the highest demand during a year $\left(42 \mathrm{kWh} / \mathrm{m}^{2}\right)$. As the cooling demand happens during the summer, having a look at the monthly solar gains and operative temperature in this period makes the results clearer. In the summer, east zone has the highest solar gains (average $5 \mathrm{kWh} / \mathrm{m}^{2}$ ), and the operative temperature rises to $35^{\circ} \mathrm{C}$. In contrast, the south zone as the coolest zone with the least solar gains needs $30 \mathrm{kWh} / \mathrm{m}^{2}$ for a year. Table 2 summarises the annual heating, cooling and total energy demands in a year. 

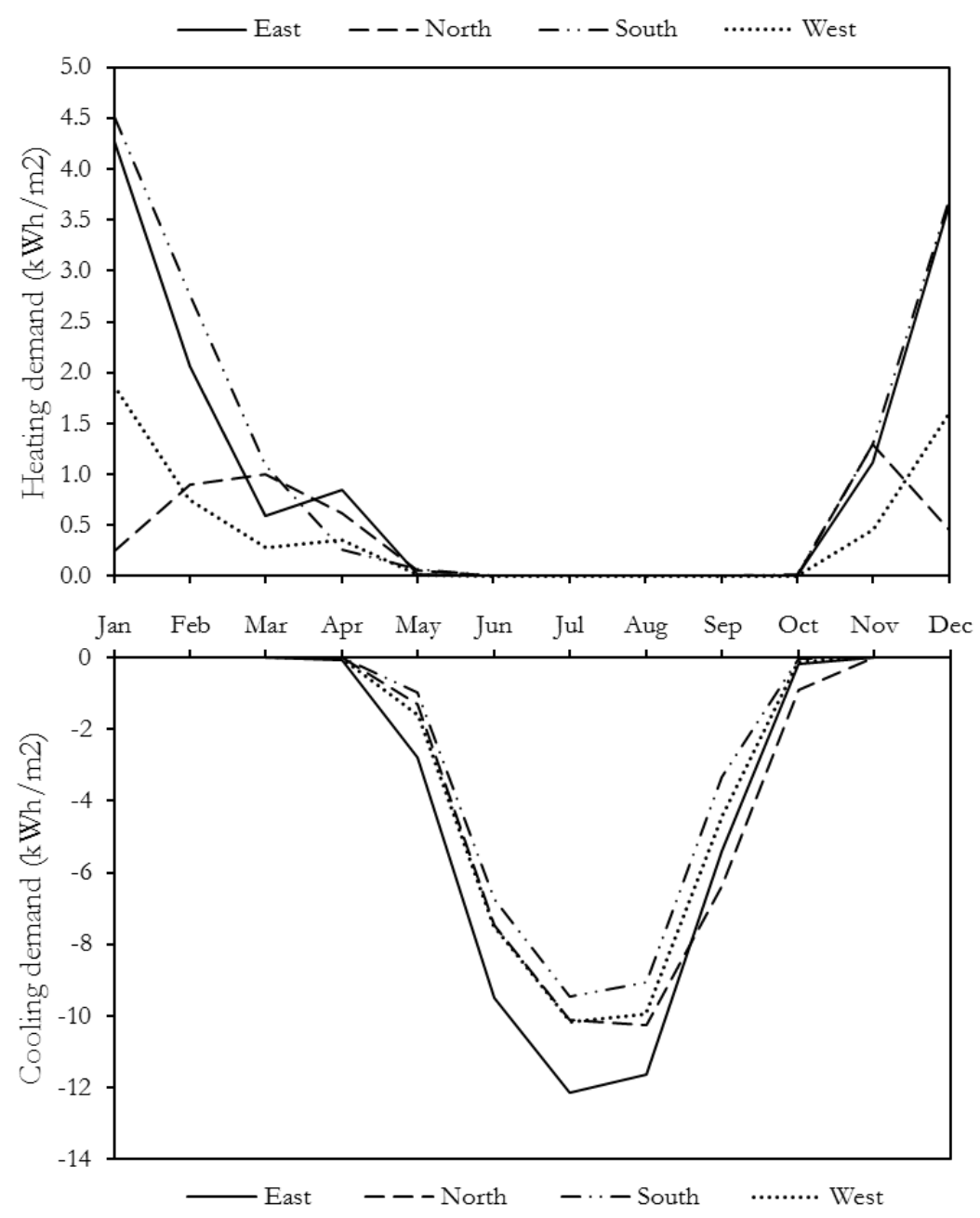

Figure 7: Monthly heating and cooling energy demands of the different zones.

Table 2: The annual heating and cooling demands of the zones.

\begin{tabular}{|l|c|c|c|c|}
\hline & East & North & South & West \\
\hline Heating $\left(\mathrm{kWh} / \mathrm{m}^{2}\right)$ & 13 & 5 & 14 & 5 \\
\hline Cooling $\left(\mathrm{kWh} / \mathrm{m}^{2}\right)$ & 42 & 36 & 30 & 34 \\
\hline Total $\left(\mathrm{kWh} / \mathrm{m}^{2}\right)$ & 54 & 41 & 43 & 39 \\
\hline
\end{tabular}

\subsubsection{The impact of zone location on indoor thermal comfort}

Based on the American Society of Heating, Refrigerating and Air-Conditioning Engineers (ASHRAE), thermal comfort is defined as "that condition of mind which expresses satisfaction with the thermal environment' [35]. Thousands of field surveys from different climates have been performed to develop the database of this thermal comfort standard [36]. In this standard, thermal comfort is calculated by indoor operative temperature and corresponding historical outdoor temperatures. 
Based on the operative temperature of each zone of the house, indoor thermal comfort is calculated for the whole year. The number of discomfortable hours are divided by the total number of hours in a year (8760 hours). The maximum discomfort hours $(69 \%)$ were in the east zone (see Figure 8). The discomfort percentage for the west, north and south zones were 64, 60 and 59\%, respectively. Figure 8 (Operative temperature panel) shows the distribution of temperature within and outside of the comfort bandwidths. It should also be noted that most of the discomfortable hours were occurred in the months of May until September (Figure 8; Discomfortable hours panel).
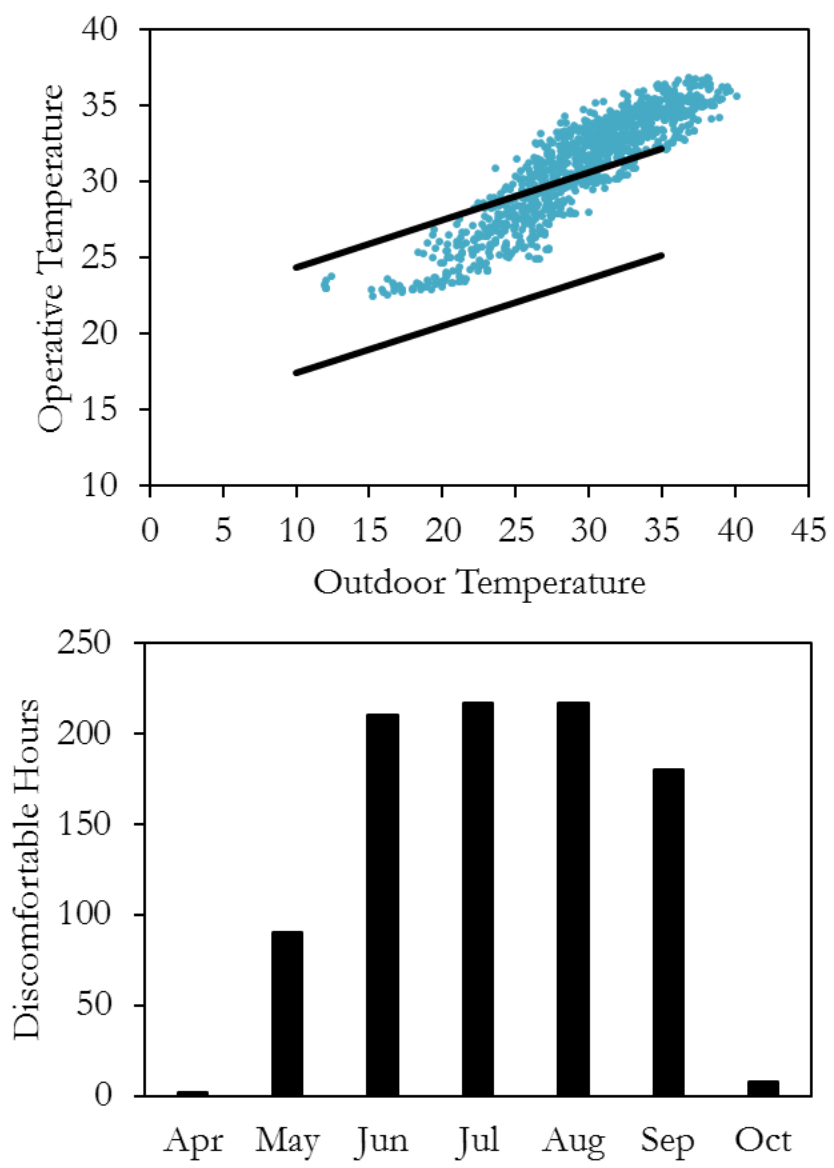

Figure 8: Distribution of indoor operative temperature within the boundaries of ASHRAE-55 thermal comfort (top). Total discomfortable hours from April to October (bottom).

\subsection{Outdoor thermal conditions}

In the second phase of this study, the outdoor thermal conditions of the courtyard house are studied. Figure 9 illustrates the diurnal profile of air temperature inside and outside of the courtyard. The temperature profiles are the average of five and four receptor points located inside and outside of the courtyard, respectively.

As the Figure shows, maximum air temperature outside of the courtyard is $34.9{ }^{\circ} \mathrm{C}$ at 15:00. At that time of the day, inside of the courtyard is $1.2^{\circ} \mathrm{C}$ cooler than the outside. One main reason for that is the heat capacity of the courtyard facades. The facades of the courtyard are covered with brick (which has a high heat capacity). This keeps the courtyard cooler than the outdoor environment (see [37, 38] for the mid-afternoon impact of surfaces on local microclimates). 15:00 is the hottest hour as the sun has radiated the 
built environment. At this time of the day, the built environment is releasing the heat (that it has absorbed since morning) back to the microclimate. This is the reason that the microclimate of the courtyard is a bit warmer than the outside during the evening and night.

The minimum temperatures occur before sunrise [39, 40], when most of the absorbed heat is dissipated (5:00 at this case). The minimum air temperatures within the courtyard is $2.0^{\circ} \mathrm{C}$ higher than the outside at 5:00. Apart the heat capacity of the brick materials, this thermal benefit is caused due to the closed shape of the courtyard. This makes the temperature fluctuations less than its outside. Deducting the maximum and minimum temperatures occurred in the whole day, it could be said that the temperature fluctuations for the inside was $12.7^{\circ} \mathrm{C}$, and $15.9^{\circ} \mathrm{C}$ for the outside.

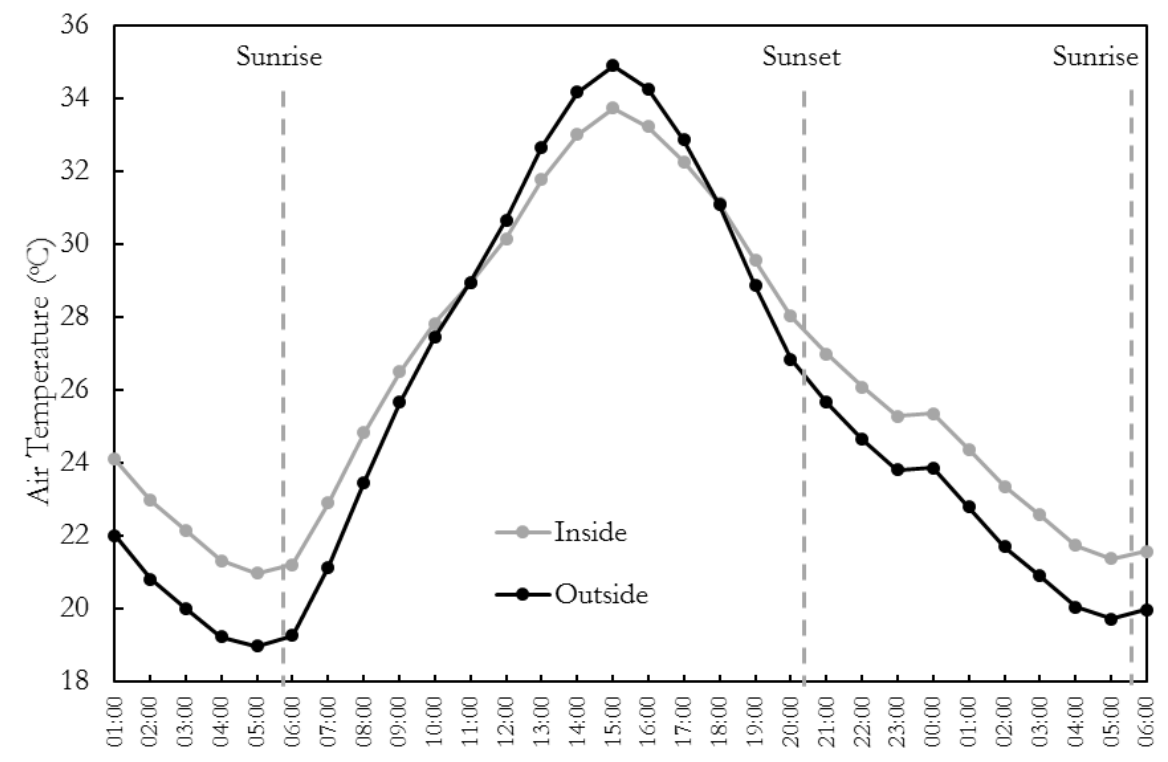

Figure 9: Temperature changes in 9 receptors

Figure 10 shows temperature changes in two sections at 15:00 (A-A in top, $B-B$ in bottom). The Figure also demonstrates the corresponding temperature of the receptors in a table.

Comparing the air temperatures from west to east in section A-A (Figure 10), receptor W2 in the west and outside of the courtyard has the highest air temperature $\left(34.5^{\circ} \mathrm{C}\right)$, where $\mathrm{W} 1$ located inside of the courtyard is $0.9^{\circ} \mathrm{C}$ cooler. At this time of the day (15:00), the sun is radiating from south west. Therefore, W1 and E2 are shaded. This makes W1 cooler than W2, and similarly, E2 is cooler than E1.

Comparing the air temperatures ranging from north to south (section B-B in Figure 10), inside of the courtyard is much cooler than the outside. Receptor S2 in the south and outside of the courtyard has the highest air temperature $\left(35.8^{\circ} \mathrm{C}\right)$, where $\mathrm{S} 1$ located inside of the courtyard (and shaded) is $2.1^{\circ} \mathrm{C}$ cooler.

In general, Figure 10 showed that the inside of the courtyard has a lower temperature than the outside. One main reason for that is the shading effect of the walls on the microclimate inside of the courtyard. Furthermore, sky view of the courtyard is lower than the outside. This makes the microclimate of the courtyard more stable, with less temperature fluctuations. 

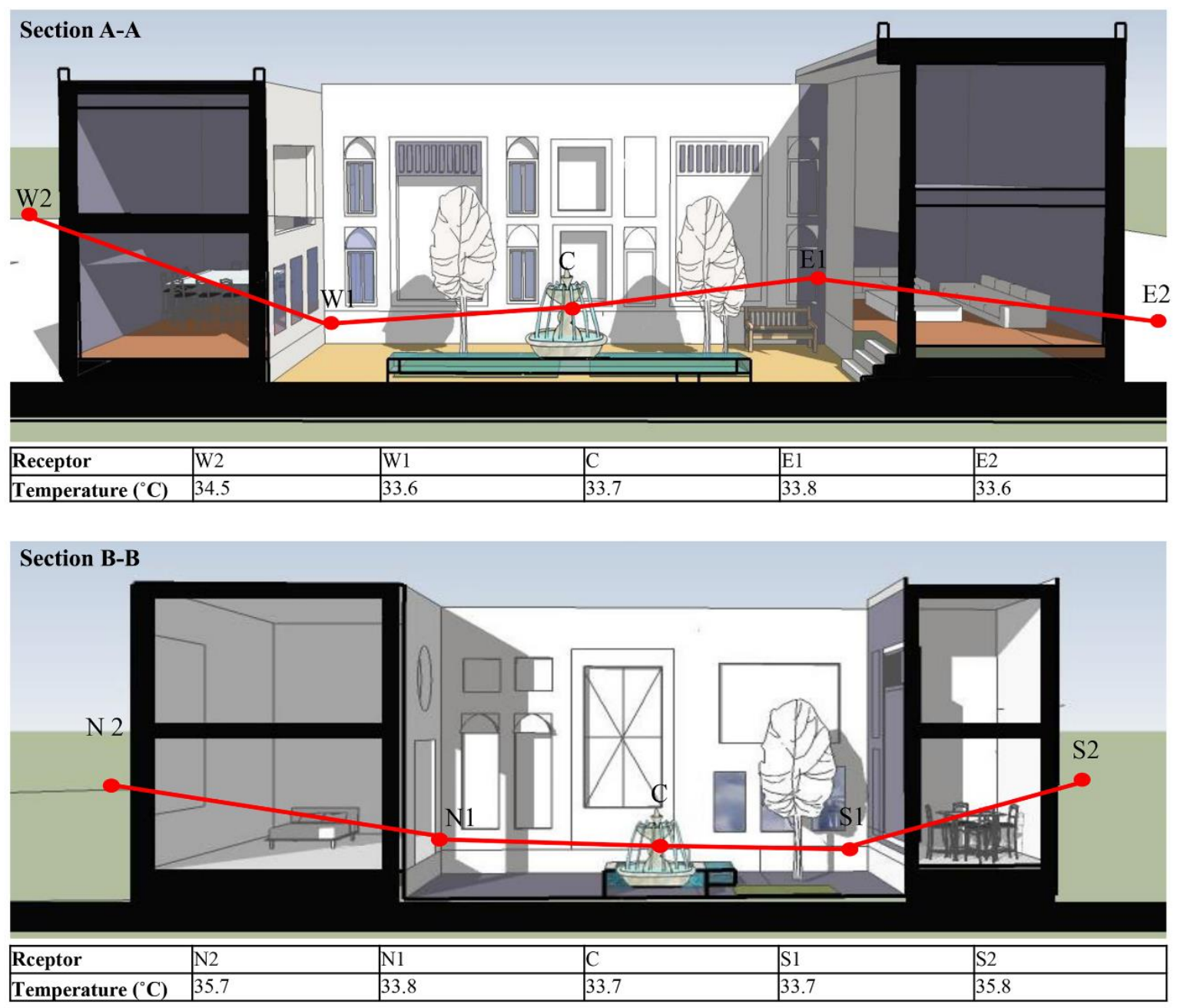

Figure 10: Temperature profiles through Section A-A (west to east, top), and Section B-B (north to south, bottom) at 15:00.

\section{Conclusions}

This paper explored the indoor and outdoor thermal conditions of a typical courtyard house in the hot arid climate of Iran. The aim was to understand the thermal performance of courtyard buildings to assist designers making better decisions. The study was performed in two phases:

In the first phase, the role of different courtyard zones on indoor operative temperature, solar gains, daylight factor, thermal comfort, and subsequently energy demand were studied. The main findings related to the indoor study were:

- The north zone needs the minimum heating energy demand $\left(5 \mathrm{kWh} / \mathrm{m}^{2}\right.$ in a year). It is suggested that this zone could be used for the most occupancy in cold seasons. 
- $\quad$ The south and east zones need the maximum heating energy demands (13 and $14 \mathrm{kWh} / \mathrm{m}^{2}$ in a year, respectively). These zones are not suggested for occupancy during cold seasons.

- $\quad$ As the east zone had the highest demand for heating during a year $\left(42 \mathrm{kWh} / \mathrm{m}^{2}\right.$ in a year), it is not suitable to be considered as the main residential space in hot seasons. In contrast, the south zone as the coolest zone with the least cooling energy demand is suggested as the most comfortable space.

- The calculation of indoor thermal comfort (based on ASHRAE-55 standard) for different zones showed that the discomfortable hours were mostly occurred from May until September. This finding could be used by designers to provide additional heat mitigation strategies for this period.

In the second phase, the outdoor microclimate of the courtyard was studied. Air temperature results from inside and outside of the courtyard were compared during the longest day of the year. The results showed that the air temperature inside of the courtyard was $1.2^{\circ} \mathrm{C}$ lower than the outside on average. Furthermore, the temperature fluctuations within the courtyard were less than the outside. This was due to main three reasons:

- The shading effect of the courtyard walls that keep the microclimate cooler;

- lower sky view factor of the courtyard compared to the outdoor environment. This fact can be used as a passive design strategy to minimise the solar gains in hot climates; and

- The brick facades of the courtyard keep the microclimate cooler than the outside during the day, and warmer during the night. This finding can be used by designers to use high heat capacity materials for buildings located in hot climates.

To sum up, this study investigated the indoor and outdoor thermal conditions of a courtyard house. Quantifying these thermal benefits of traditional passive design strategies make it easier for designer to use them in contemporary buildings.

\section{Reference:}

1. Taleghani, M., Dwelling on Courtyards: Exploring the energy efficiency and comfort potential of courtyards for dwellings in the Netherlands. 2014, Delft University of Technology.

2. Edwards, B., Courtyard Housing: Past, Present, Future. 2006: Taylor \& Francis Group.

3. Sözen, i. and G.K. Oral, Outdoor thermal comfort in urban canyon and courtyard in hot arid climate: A parametric study based on the vernacular settlement of Mardin. Sustainable Cities and Society, 2019.

4. Shashua-Bar, L., D. Pearlmutter, and E. Erell, The influence of trees and grass on outdoor thermal comfort in a hot-arid environment. International Journal of Climatology, 2011. 31(10): p. 1498-1506.

5. Nasrollahi, N., et al., Numerical evaluation of thermal comfort in traditional courtyards to develop new microclimate design in a hot and dry climate. Sustainable Cities and Society, 2017. 35: p. 449-467.

6. Dash, M. and M. Chakraborthy, Influence of climate on building codes: Comparative analysis of indian cities. Environmental Progress \& Sustainable Energy, 2018.

7. Rodríguez-Algeciras, J., et al., Influence of aspect ratio and orientation on large courtyard thermal conditions in the historical centre of Camagüey-Cuba. Renewable Energy, 2018. 125: p. $840-856$. 
8. Acosta, I., et al., Energy efficiency and lighting design in courtyards and atriums: A predictive method for daylight factors. Applied Energy, 2018. 211: p. 1216-1228.

9. Aldawoud, A. and R. Clark, Comparative analysis of energy performance between courtyard and atrium in buildings. Energy and Buildings, 2008. 40(3): p. 209-214.

10. Masoumi, H.R., N. Nejati, and A.a. Ahadi, Learning from the Heritage Architecture: Developing Natural Ventilation in Compact Urban Form in Hot-Humid Climate: Case Study of Bushehr, Iran. International Journal of Architectural Heritage, 2017. 11(3): p. 415-432.

11. Taleghani, M., M. Tenpierik, and A. Dobbelsteen, The Effect of Different Transitional Spaces on Thermal Comfort and Energy Consumption of Residential Buildings, in 7th Windsor Conference: The changing context of comfort in an unpredictable world Cumberland Lodge. 2012, Network for Comfort and Energy Use in Buildings: Windsor, UK.

12. Mohsenin, M. and J. Hu, Assessing daylight performance in atrium buildings by using Climate Based Daylight Modeling. Solar Energy, 2015. 119: p. 553-560.

13. Muhaisen, A.S., Shading simulation of the courtyard form in different climatic regions. Building and Environment, 2006. 41(12): p. 1731-1741.

14. Yaşa, E. and V. Ok, Evaluation of the effects of courtyard building shapes on solar heat gains and energy efficiency according to different climatic regions. Energy and Buildings, 2014. 73: p. 192-199.

15. Yang, X., Y. Li, and L. Yang, Predicting and understanding temporal 3D exterior surface temperature distribution in an ideal courtyard. Building and Environment, 2012. 57: p. 38-48.

16. Akbari, H. and S. Konopacki, Calculating energy-saving potentials of heat-island reduction strategies. Energy Policy, 2005. 33(6): p. 721-756.

17. Huang, K.-T. and Y.-J. Li, Impact of street canyon typology on building's peak cooling energy demand: A parametric analysis using orthogonal experiment. Energy and Buildings, 2017. 154: p. 448-464.

18. Zamani, Z., S. Heidari, and P. Hanachi, Reviewing the thermal and microclimatic function of courtyards. Renewable and Sustainable Energy Reviews, 2018. 93: p. 580-595.

19. Haji Ghasemi, K., Isfahan Houses. Ganj-Nameh. 2014: Shahid Beheshti University.

20. DesignBuilder, http://www. designbuilder.co.uk. 2017(Accessed 17.02.2017).

21. EnergyPlus, EnergyPlus Development Team. Input output reference: the encyclopedic reference to EnergyPlus input and output. EnergyPlus 2010; version 6.0. 2010.

22. EnergyPlus. Isfahan Weather Data (ITMY). 2017; Accessed 05.01.2017:[Available from: https://energyplus.net/weatherlocation/asia wmo region 2/IRN//IRN Esfahan.408000 ITMY.

23. Baniassadi, A., et al., Direct and indirect effects of high-albedo roofs on energy consumption and thermal comfort of residential buildings. Energy and Buildings, 2018. 178: p. 71-83.

24. Ghahramani, A., et al., Energy savings from temperature setpoints and deadband: Quantifying the influence of building and system properties on savings. Applied Energy, 2016. 165: p. 930-942.

25. Zamani, Z., M. Taleghani, and S.B. Hoseini, Courtyards as solutions in green architecture to reduce environmental pollution. Energy Education Science \& Technology, Part A: Energy Science and Research, 2012. 30(1): p. 358-396.

26. Bruse, M. ENVI-met website. 2018; Accessed 20.10.2018 [Available from: http://www.envimet.com.

27. Bruse, M., ENVI-met 3.0: Updated Model Overview, in Accessed 02.10.2018 2004: http://www.envi-met.net/documents/papers/overview30.pdf. 
28. Nasrollahi, N., Z. Hatami, and M. Taleghani, Development of outdoor thermal comfort model for tourists in urban historical areas; A case study in Isfahan. Building and Environment, 2017. 125: p. 356-372.

29. Taleghani, M. and U. Berardi, The effect of pavement characteristics on pedestrians' thermal comfort in Toronto. Urban Climate, 2018. 24: p. 449-459.

30. Kleerekoper, L., et al., Urban measures for hot weather conditions in a temperate climate condition: A review study. Renewable and Sustainable Energy Reviews, 2017. 75: p. 515533.

31. Forouzandeh, A., Numerical modeling validation for the microclimate thermal condition of semi-closed courtyard spaces between buildings. Sustainable Cities and Society, 2018. 36: p. 327-345.

32. Kottek, M., et al., World Map of the Köppen-Geiger climate classification updated. Meteorologische Zeitschrift, 2006. 15(3).

33. Ahmadalipour, A. and H. Moradkhani, Escalating heat-stress mortality risk due to global warming in the Middle East and North Africa (MENA). Environment International, 2018. 117: p. 215-225.

34. Modarres, R., et al., Future heat stress arising from climate change on Iran's population health. International Journal of Biometeorology, 2018. 62(7): p. 1275-1281.

35. ASHRAE, ASHRAE Standard 55-2013 in Thermal Environmental Conditions for Human Occupancy. 2013, ASHRAE Atlanta, GA.

36. deDear, R.J. and G.S. Brager, Thermal comfort in naturally ventilated buildings: revisions to ASHRAE Standard 55. Energy and Buildings, 2002. 34(6): p. 549-561.

37. Vanos, J.K., et al., Hot playgrounds and children's health: A multiscale analysis of surface temperatures in Arizona, USA. Landscape and Urban Planning, 2016. 146: p. 29-42.

38. Taleghani, M., The impact of increasing urban surface albedo on outdoor summer thermal comfort within a university campus. Urban Climate, 2018. 24: p. 175-184.

39. Oke, T.R., Boundary Layer Climates. 2002, London: Taylor \& Francis.

40. Oke, T.R., et al., Urban Climates. 2017: Cambridge University Press. 